\title{
Pengaruh lama mengunyah terhadap kadar glukosa postprandial dewasa obesitas
}

\author{
Arin Wulansari ${ }^{*}$, Fryta Ameilia L. ${ }^{2}$, Fuadah Uyun ${ }^{1}$, Dwi Retnoningrum ${ }^{3}$, Fifin Luthfia Rahmi ${ }^{4}$, Arief Wildan $^{4}$
}

\section{ABSTRACT}

Background: Obesity cause various physiological changes in the body, one of which is insulin resistance causes high blood glucose levels. Chewing is a stimulus of cephalic phase responses and sensory stimulation that can increase hormones releasing such as insulin, ghrelin, cholecystokinin (CCK) and glucagon like peptide-1 (GLP-1). Chewing plays important role in determining postprandial plasma glucose concentration.

Objective: Investigate the effect of chewing on postprandial blood glucose in obese adults.

Method: This was true experimental research. Research subjects were treated in the form of chewing 22 times and 40 times each mouthful. Blood glucose levels were measured using glucometer on fasting blood glucose and postprandial blood glucose 15 minutes, 30 minutes, 60 minutes, and 120 minutes. Statistical test using Independent $t$-test.

Results: The mean postprandial glucose levels in the 22 chews group at 15 minutes, 30 minutes, 60 minutes, and 120 minutes were $112.11 \pm 14.3328,126.11 \pm 15.667,116.94 \pm 15.539$, and $89.67 \pm 11.668$. While the mean postprandial blood glucose levels in the 40 chews group at 15 minutes, 30 minutes, 60 minutes, and 120 minutes were 122.22 $\pm 14.381,129.61 \pm 15.112$, $109.50 \pm 14.995$, and $85.83 \pm 13.963$. There were statistically significant differences between chewing groups 22 times and chewing 40 times on fasting blood glucose and 15 minutes postprandial blood glucose $(p=0.041$ and $p=0.042)$, while on 30 minutes postprandial glucose testing, 60 minutes, and 120 minutes there was no significant difference $(p>0.05)$.

Conclusion: There was significant differences in 15 minutes postprandial blood glucose level between group 22 times chewing and 40 times chewing each mouthful.

Keywords: obesity; chewing; blood glucose; glucometer

\section{ABSTRAK}

Latar belakang: Obesitas menyebabkan berbagai perubahan fisiologis pada tubuh, salah satunya resistensi insulin yang dapat menyebabkan kadar glukosa dalam darah tinggi. Mengunyah adalah stimulus dari respon fase sefalik dan stimulasi sensorik yang dapat meningkatkan pelepasan hormon-hormon seperti insulin, ghrelin, cholesistokinin (CCK) dan glucagon like peptide1 (GLP-1). Mengunyah memainkan peran penting dalam menentukan konsentrasi glukosa plasma postprandial.

Tujuan: Mengetahui pengaruh lama mengunyah terhadap glukosa darah postprandial pada dewasa obesitas.

Metode: Penelitian ini menggunakan metode eksperimental. Subjek penelitian diberi perlakuan berupa mengunyah sebanyak 22 kali dan 40 kali tiap suapan. Kadar glukosa darah diukur menggunakan glukometer pada glukosa darah puasa dan glukosa darah postprandial 15 menit, 30 menit, 60 menit, dan 120 menit. Uji statistik menggunakan independent t-test.

Hasil: Rerata kadar glukosa postprandial pada kelompok mengunyah 22 kali pada 15 menit, 30 menit, 60 menit, dan 120 menit

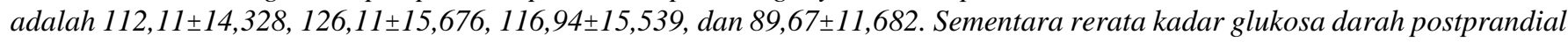

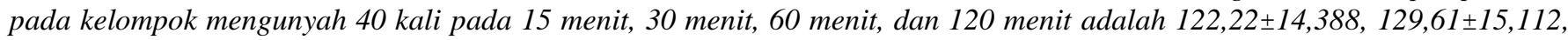

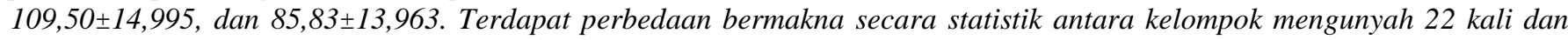
mengunyah 40 kali dengan kadar glukosa darah puasa dan glukosa darah postprandial 15 menit $(p=0,041$ dan p=0,042), sedangkan pada pemeriksaan glukosa postprandial 30 menit, 60 menit, dan 120 menit terdapat perbedaan yang tidak bermakna $(p>0,05)$.

Kesimpulan: Didapatkan perbedaan bermakna pada kadar glukosa darah postprandial 15 menit antara kelompok mengunyah 22 kali dan mengunyah 40 kali tiap suapan.

Kata Kunci: obesitas; mengunyah; glukosa darah; glukometer

\section{PENDAHULUAN}

Permasalahan obesitas tidak hanya terjadi di Indonesia, tetapi juga di dunia, baik di negara maju maupun negara berkembang. Menurut data World
Health Organization (WHO) pada tahun 2016 lebih dari 1,9 milyar dewasa mengalami overweight dengan lebih dari 650 juta diantaranya adalah obesitas. Di Indonesia, menurut hasil Riset Kesehatan Dasar (Riskesdas) 2013 sebanyak 15,4\% mengalami obesitas dan 13,5\%

\footnotetext{
${ }^{1}$ Program Studi Kedokteran Umum, Fakultas Kedokteran, Universitas Diponegoro. Jl. Prof. Soedarto, S.H, Tembalang, Semarang, Jawa Tengah 50275, Indonesia

${ }^{2}$ Departemen Ilmu Gizi, Fakultas Kedokteran, Universitas Diponegoro. J1. Prof. Soedarto, S.H, Tembalang, Semarang, Jawa Tengah 50275, Indonesia

${ }^{3}$ Bagian Patologi Klinik, Fakultas Kedokteran, Universitas Diponegoro. Jl. Prof. Soedarto, S.H, Tembalang, Semarang, Jawa Tengah 50275, Indonesia

${ }^{4}$ Bagian Ilmu Kesehatan Mata, Fakultas Kedokteran, Universitas Diponegoro. Jl. Prof. Soedarto, S.H, Tembalang, Semarang, Jawa Tengah 50275, Indonesia

${ }^{*}$ Korespondensi : E-mail: arinwulansari@ student.undip.ac.id
} 
mengalami overweight. ${ }^{1,2}$

Obesitas adalah kondisi multifaktorial yang dipengaruhi oleh banyak variabel termasuk faktor genetik, demografi, dan gaya hidup. Beberapa studi menemukan bahwa kebiasaan makan dengan cepat dan jumlah kunyahan yang sedikit berhubungan dengan terjadinya obesitas. ${ }^{3-5}$ Obesitas tidak hanya dianggap sebagai penyakit itu sendiri, tetapi juga menimbulkan dan memperparah kondisi patologis lainnya, dan dikenal sebagai faktor risiko untuk penyakit kronis tertentu, seperti diabetes. ${ }^{6}$ Penimbunan lemak yang berlebihan atau obesitas dapat menyebabkan berbagai perubahan fisiologis pada tubuh, salah satunya terjadi resistensi insulin yang merupakan penyebab sindrom metabolik. Insulin berperan dalam meningkatkan ambilan glukosa di sel dan juga mengatur metabolisme karbohidrat. Resistensi insulin dapat menyebabkan kadar glukosa darah tinggi. ${ }^{7-9}$

Mengunyah adalah stimulus dari respon fase sefalik dan stimulasi sensorik yang dapat meningkatkan pelepasan hormon-hormon seperti insulin, ghrelin, Cholesistokinin (CCK) dan glucagon like peptide-1 (GLP-1). Pelepasan insulin pada fase preabsorptif atau sefalik merupakan vagally mediated response yang terjadi dalam beberapa menit pertama dalam pencernaan makanan dan dianggap diperlukan untuk toleransi glukosa postprandial normal. Dengan demikian, mastikasi memainkan peran penting dalam menentukan konsentrasi glukosa plasma postprandial. Penelitian menunjukkan bahwa konsentrasi glukosa plasma, insulin, dan glucose-dependent insulinotropic peptide (GIP) meningkat signifikan setelah makan pada kelompok mengunyah 40 kali dan kemudian mengalami penurunan signifikan selama kurun waktu postprandial. ${ }^{10-12}$

Makanan yang dicerna dengan cepat akan menyebabkan efisiensi rasa kenyang yang lebih rendah. Hal ini disebabkan oleh karakteristik seperti ukuran gigitan yang besar, aktivitas menunyah yang rendah, dan exposure time oro-sensori yang rendah. Ukuran gigitan yang kecil dan aktivitas mengunyah yang lebih banyak akan menyebabkan exposure time oro-sensori lebih lama dan menurunkan asupan makanan. Kecepatan makan yang lebih lambat dan mengunyah yang lama memodulasi kontrol impuls dan lamanya pengunyahan akan memperkecil ukuran makanan, meningkatkan sensitivitas rasa lapar, dan menurunkan asupan makanan. Kecepatan makan yang cepat berhubungan dengan tingginya angka indeks massa tubuh (IMT) dan obesitas. Intervensi kecepatan makan seperti memperlama mengunyah meningkatkan exposure time oro-sensori, regulasi ghrelin, glucagon like peptide-1 (GLP-1), peptide Y (PYY), dan regulasi rasa kenyang dan asupan makan, yang menyebabkan penurunan berat badan. ${ }^{13,14}$
Mengunyah memiliki peran utama dalam pencernaan makanan dan mempengaruhi rasa kenyang (food intake), respon rasa kenyang postprandial, atau berat badan melalui beberapa mekanisme. Mengunyah meningkatkan luas permukaan per unit volume makanan padat yang kemungkinan dengan meningkatkan jumlah siklus mengunyah sebelum menelan akan meningkatkan luas permukaan efektif pada bolus makanan yang ditelan. Karena laju kerja enzim sebanding dengan luas permukaan partikel bolus yang ditelan dapat mengubah kinetika digestif dan respon metabolik atau endokrin postprandial. Selain itu mengunyah, juga secara mekanik akan memecah dinding sel makanan yang akan melepaskan makronutrien yang mungkin tidak dapat dicapai oleh tubuh sehingga pemecahan makanan melalui peningkatan jumlah mengunyah dapat meningkatkan energi yang tersedia dari makanan dan keseimbangan energi positif. Peningkatan pemecahan makronutrien juga dapat menambah rasa kenyang melalui peningkatan sekresi hormon yang berhubungan dengan nafsu makan. ${ }^{15}$

Mengunyah akan memecah makanan menjadi ukuran yang lebih kecil, menstimulasi saliva, mencampur makanan dengan enzim, dan meningkatkan hidrolisis karbohidrat di mulut dan organ pencernaan serta meningkatkan respon glikemik dan insulinemik. Selain itu, mengunyah juga meningkatkan daya cerna dengan meningkatkan permukaan untuk aksi berbagai enzim. Hal inilah yang akan membantu stimulasi fase sefalik dalam pelepasan insulin dan inkretin dari usus untuk meningkatkan absorpsi karbohidrat sederhana seperti glukosa. Fase sefalik merujuk pada refleks fisiologis yang ditimbulkan oleh rangsangan yang melibatkan reseptor pada orofaring. Faktor yang mempengaruhi peningkatan respon insulin fase sefalik meliputi aroma dan tampilan makanan serta durasi stimulasi sensorik pada rongga mulut. ${ }^{11,25,26}$

Kecepatan makan yang cepat, ukuran tiap gigitan yang besar, dan waktu pemrosesan oral yang singkat dapat meningkatkan terjadinya makan berlebih (overeating) dan berhubungan dengan peningkatan atau penambahan berat badan. Edukasi gizi yang dipadukan dengan terapi perilaku makan merupakan salah satu cara efektif dalam penanggulangan obesitas. ${ }^{14,16,17}$ Penelitian ini bertujuan untuk mengetahui pengaruh lama mengunyah terhadap glukosa darah postprandial pada dewasa obesitas.

\section{BAHAN DAN METODE}

Penelitian ini merupakan penelitian eksperimental dengan rancangan two group pre test and post test design. Penelitian dilaksanakan di Fakultas Kedokteran Universitas Diponegoro pada bulan April - Juli 2018. Subjek penelitian adalah penderita obesitas yang berada di lingkungan Fakultas Kedokteran Universitas 
Diponegoro Semarang pada periode penelitian dengan kriteria inklusi adalah memiliki IMT $\geq 25 \mathrm{~kg} / \mathrm{m}^{2}$, bersedia mengikuti penelitian, mampu mengonsumsi makanan yang diberikan, dapat menjalani puasa selama 8-10 jam sebelum dilakukan tes, dan cukup tidur serta tidak sedang melakukan aktivitas fisik berat. Kriteria eksklusi penelitian ini adalah menjalani diet khusus, mengonsumsi obat-obatan yang dapat mempengaruhi glukosa darah, dan diabetes mellitus. Besar subjek penelitian diukur dengan menggunakan rumus besar sampel untuk penelitian beda rerata 2 kelompok subjek sebanyak 18 orang yang terdiri dari 8 laki-laki dan 10 wanita antara usia 18-24 tahun yang memiliki GDP <126 $\mathrm{mg} / \mathrm{dl}$. Penelitian ini menggunakan kelompok yang sama yang diberikan dua perlakuan yang berbeda.

Pemilihan subjek penelitian menggunakan purposive sampling. Subjek penelitian yang memenuhi kriteria inklusi diminta untuk melakukan puasa pada malam sebelumnya selama 8-10 jam dan dilakukan pengukuran kadar glukosa darah puasa menggunakan glukometer. Subjek yang memiliki kadar glukosa darah puasa (GDP) $<126 \mathrm{mg} / \mathrm{dl}$ diberikan makanan berupa satu porsi nasi menurut Badan Ketahanan Pangan sebesar 100 gram nasi dan 60 gram telur dadar yang terbagi menjadi 10 bagian (suapan) dengan setiap bagian terdiri dari nasi dan telur tanpa diberikan tambahan buah atau sayur. Satu bagian tersebut untuk satu suapan. Setiap subjek diberikan makanan dengan porsi yang sama tanpa menghitung berat badan ataupun kebutuhan sehariharinya. Tiap suapan dengan jumlah kunyahan 22 kali kunyahan (didapatkan berdasarkan rata-rata mengunyah pada subjek penelitian melalui penelitian pendahuluan) kemudian dilakukan perhitungan kadar glukosa darah postprandial (GDPP) 15 menit, 30 menit, 60 menit, dan 120 menit menggunakan glukometer. Rentang 1 minggu dilakukan perlakuan yang sama dengan jumlah kunyahan sebanyak 40 kali.

Variabel bebas dalam penelitian ini adalah jumlah kunyahan pada tiap suapan makanan dan variabel terikat dalam penelitian ini adalah kadar glukosa darah postprandial. Data glukosa darah postprandial yang telah diperoleh dilakukan uji normalitas dengan menggunakan Shapiro-Wilk. Analisis data untuk melihat perbedaan antara kelompok 22 kali kunyahan dengan 40 kali kunyahan dilakukan dengan uji independent t-test.

Penelitian telah mendapatkan Ethical Clearance dari Komisi Etik Penelitian Kesehatan (KEPK) Fakultas Kedokteran Universitas Diponegoro RSUP Dr. Kariadi Semarang dengan nomor 380/EC/FK-RSDK/V/2018. Seluruh subjek penelitian sudah menyetujui menjadi sampel penelitian dengan menandatangani lembar informed consent.

\section{HASIL}

Tabel 1 menunjukkan bahwa pada populasi subjek penelitian lebih banyak berjenis kelamin perempuan sebanyak 10 orang $(55,6 \%)$ sedangkan laki-laki sebanyak 8 orang $(44,4 \%)$. Nilai median umur subjek penelitian sebesar 21 dengan umur termuda 18 dan usia tertua 22 tahun. Rerata IMT yang dimiliki subjek penelitian adalah $31,76 \pm 4,394 \mathrm{~kg} / \mathrm{m}^{2}$.

Tabel 1. Karakteristik Subjek Penelitian

\begin{tabular}{|c|c|c|c|}
\hline Karakteristik & n (\%) & Rerata \pm SD & Median (Min-Maks) \\
\hline \multicolumn{4}{|l|}{ Jenis Kelamin } \\
\hline Laki-laki & $8(44,4 \%)$ & & \\
\hline Perempuan & $10(55,6 \%)$ & & \\
\hline Umur (tahun) & & $20,22 \pm 1,215$ & $21(18-22)$ \\
\hline $\operatorname{IMT}\left(\mathrm{kg} / \mathrm{m}^{2}\right)$ & & $31,76 \pm 4,394$ & $31,02(25-39)$ \\
\hline
\end{tabular}

Tabel 2. Hasil Uji Beda Glukosa Darah Postprandial Antarkelompok

\begin{tabular}{llll}
\hline Kadar Glukosa & $\begin{array}{l}\text { Mengunyah 22 kali } \\
\text { (rerata } \pm \text { SD) } \mathbf{~ m g / d l}\end{array}$ & $\begin{array}{l}\text { Mengunyah 40 kali } \\
\text { (rerata } \pm \text { SD) mg/dl }\end{array}$ & Nilai $\boldsymbol{p}$ \\
\hline GDP & $83,89 \pm 8,643$ & $90,17 \pm 9,051$ & 0,041 \\
GDPP (15 menit) & $112,11 \pm 14,328$ & $122,22 \pm 14,388$ & 0,042 \\
GDPP (30 menit) & $126,11 \pm 15,676$ & $129,61 \pm 15,112$ & 0,500 \\
GDPP (60 menit) & $116,94 \pm 15,539$ & $109,50 \pm 14,995$ & 0,153 \\
GDPP (120 menit) & $89,67 \pm 11,682$ & $85,83 \pm 13,963$ & 0,378 \\
\hline
\end{tabular}

*Independent $t$-test

\section{Perbedaan Kadar Glukosa Darah pada Mengunyah 22 Kali dan Mengunyah 40 Kali Tiap Suapan}

Tabel 2 menunjukkan bahwa secara statistik terdapat perbedaan bermakna antara kelompok mengunyah 22 kali dengan kelompok mengunyah 40 kali pada pemeriksaan kadar glukosa darah postprandial
15 menit $(\mathrm{p}<0,05)$. Pada pemeriksaan kadar glukosa darah postprandial 30 menit, 60 dan 120 menit disimpulkan tidak terdapat perbedaan bermakna secara statistik antara kadar glukosa darah kelompok yzng mengunyah 22 kali dengan kelompok yang mengunyah 40 kali. 


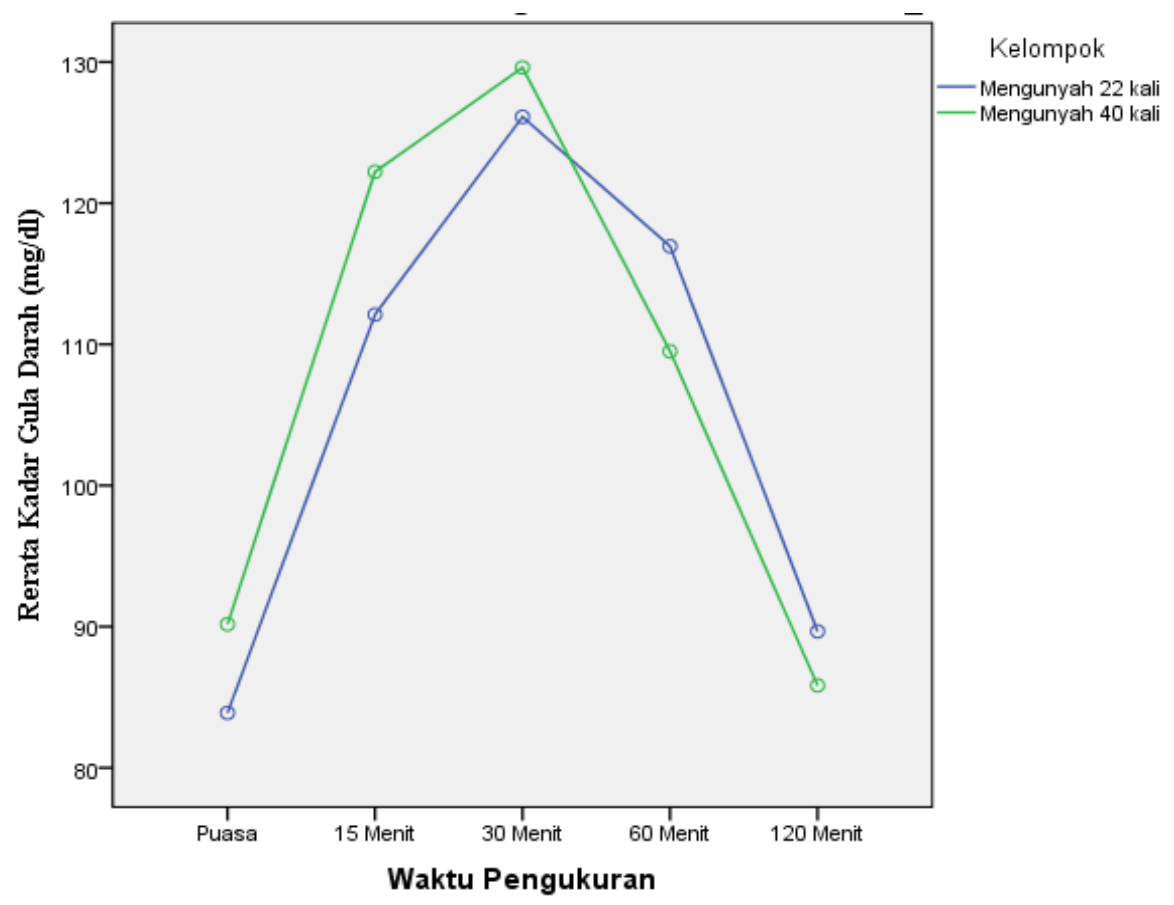

Gambar 1. Diagram Perubahan Kadar Glukosa Darah pada Kelompok Mengunyah 22 Kali dan 40 Kali Tiap Suapan

Gambar 1 menunjukkan kadar glukosa darah postprandial pada kedua kelompok mencapai puncak pada menit 30 , didapatkan hasil rata-rata $126,11 \mathrm{mg} / \mathrm{dl}$ dengan simpangan baku sebesar 15,676 pada kelompok mengunyah 22 kali tiap suapan dan didapatkan hasil ratarata 129,61 mg/dl dengan simpangan baku sebesar 15,112 pada kelompok mengunyah 40 kali tiap suapan. Selanjutnya pada kelompok mengunyah 22 kali tiap suapan dan kelompok mengunyah 40 kali tiap suapan, terdapat penurunan kadar glukosa postprandial pada 60 dan 120 menit, tetapi tidak terdapat perbedaan bermakna antar kelompok. Gambar 1 menunjukkan bahwa kelompok mengunyah 40 kali tiap suapan terjadi penurunan kadar glukosa postprandial yang lebih rendah walaupun memiliki kadar GDP yang lebih tinggi dibanding dengan kelompok 22 kali mengunyah tiap suapan.

\section{PEMBAHASAN}

Obesitas merupakan abnormalitas atau berlebihnya akumulasi lemak yang diakibatkan dari kelebihan asupan energi dibandingkan dengan yang diperlukan oleh tubuh. ${ }^{7,18}$ Kebiasaan makan seperti makan dengan cepat berdampak pada terjadinya kelebihan berat badan. Memperpanjang waktu saat mengunyah dapat mencegah overeating dan berkontribusi untuk menurunkan asupan makanan yang dikonsumsi. Penelitian ini membandingkan perbedaan pengaruh lama mengunyah terhadap kadar glukosa postprandial pada dewasa obesitas. Pemilihan jumlah lama mengunyah sesuai dengan rerata lama mengunyah pada subjek obesitas sebesar 22 kali yang diperoleh dari penelitian pendahuluan dan merujuk pada penelitian oleh Jie Li, dkk yang meneliti hal serupa dengan lama mengunyah sebesar 40 kali. $^{5}$

Pada kedua kelompok terdapat perbedaan GDP meskipun data diambil dari populasi yang sama. Hal ini dapat dipengaruhi oleh beberapa faktor seperti durasi tidur dan stres yang terjadi semalam sebelumnya dan mengakibatkan resistensi insulin. ${ }^{19,20}$ Terdapat perbedaan signifikan pada kadar glukosa postprandial 15 menit antara kelompok mengunyah 22 kali dan 40 kali tiap suapan yang mendukung penelitian sebelumnya yang menggunakan model hewan coba dan subjek manusia menunjukkan bahwa peningkatan aktivitas mengunyah memudahkan absorpsi glukosa. ${ }^{21-24}$

Mengunyah merupakan langkah pertama dalam proses pencernaan dan berfungsi dalam menyiapkan makanan untuk ditelan dan diproses lebih lanjut pada sistem pencernaan. Mengunyah akan memecah makanan menjadi ukuran yang lebih kecil, menstimulasi saliva, mencampur makanan dengan enzim, dan meningkatkan hidrolisis karbohidrat di mulut dan organ pencernaan serta meningkatkan respon glikemik dan insulinemik. Selain itu, mengunyah juga meningkatkan daya cerna dengan meningkatkan permukaan untuk aksi berbagai enzim. Hal inilah yang akan membantu stimulasi fase sefalik dalam pelepasan insulin dan inkretin dari usus untuk meningkatkan absorpsi karbohidrat sederhana seperti glukosa. Fase sefalik merujuk pada refleks fisiologis yang ditimbulkan oleh rangsangan yang melibatkan reseptor pada orofaring. Faktor yang mempengaruhi peningkatan respon insulin fase sefalik meliputi aroma dan tampilan makanan serta durasi stimulasi sensorik pada rongga mulut. ${ }^{11,25,26}$

Pankreas memiliki banyak inervasi yang berasal dari sistem saraf simpatis maupun parasimpatis. Serabut saraf simpatis terutama ditemukan pada splanchnic 
nerve, sedangkan serabut saraf parasimpatik dapat ditemukan pada nervus vagus. Berdasarkan penelitian sebelumnya, ${ }^{27,28}$ faktor saraf berperan penting dalam pola normal sekresi insulin. Terdapat dua tahapan sebelum late enteric stage ketika zat gizi diabsorbsi. Selama fase sefalik pada kelompok mengunyah lama, pelepasan asetilkolin dimungkinkan distimulasi lebih kuat dibandingkan dengan kelompok yang mengunyah seperti biasanya melalui aktivasi vagal-efferent fibers. Kemudian, pada fase early-enteric, ketika neuron pada sistem saraf enterik diaktifkan oleh zat gizi yang masuk ke usus, mengunyah lama dapat meningkatkan pelepasan kolesistokinin dengan menambah pengosongan lambung. Dengan demikian, asetilkolin dan kolesistokinin dapat berkontribusi untuk sekresi earlyphase insulin pada kelompok mengunyah lama yang memiliki toleransi glukosa normal.

Pemecahan karbohidrat komplek menjadi monosakarida juga akan menstimulasi munculnya inkretin yang bertindak sebagai insulinotropik untuk menginduksi insulin. ${ }^{29,30}$ Peningkatan kadar insulin menyebabkan inhibisi terhadap neuron neuropeptida Y/ Agouti-related protein (NPY/AgRP) dan stimulasi neuron proopiomelanocortin (POMC) yang menghambat nafsu makan sehingga menurunkan asupan makanan. Selain itu, adanya makanan yang masuk lambung juga menurunkan kadar ghrelin yang merupakan penstimulasi nafsu makan saat lambung kosong. ${ }^{29-32}$

Pengurangan frekuensi mengunyah pada orang dengan makan cepat dan inaktivasi histamin neural dimungkinkan berhubungan dengan peningkatan berat badan. Mastikasi menginduksi aktivasi neuron histamin yang menekan asupan makanan melalui reseptor $\mathrm{H} 1$ pada nukleus paraventrikular hipotalamus dan nukleus ventromedial hipotalamus yang diketahui sebagai pusat kenyang. ${ }^{26}$

Hasil pemeriksaan kadar glukosa darah pada kelompok 22 kali mengunyah tiap suapan dan 40 kali mengunyah tiap suapan mengalami puncak kadar glukosa darah tertinggi pada 30 menit setelah makan. Setelah dilakukan analisis, secara statistik tidak terdapat perbedaan bermakna diantara keduanya $(p=0,500)$. Puncak kenaikan glukosa darah yang terjadi setelah konsumsi makanan tergantung dari kecepatan pencernaan dan penyerapan karbohidrat dalam tubuh manusia dan sensitivitas hormon insulin masing-masing subjek. Kadar glukosa darah akan kembali normal setelah dua atau tiga jam. ${ }^{33} \mathrm{Hal}$ ini mendukung penelitian sebelumnya oleh Suzuki, dkk yang menyatakan bahwa kadar glukosa plasma dan insulin serum mengalami peningkatan kadar glukosa postprandial 30 menit pada kelompok subjek yang memiliki glukosa toleransi yang normal, dan konsentrasi insulin serum pada kelompok mengunyah lama secara signifikan lebih tinggi dibandingkan pada kelompok yang mengunyah seperti biasanya. $^{11}$

Peningkatan jumlah kunyahan dapat melepaskan zat gizi dari makanan secara lebih efisien, yang kemudian mempengaruhi pemberian sinyal usus, physical actions, dan akhirnya proses pencernaan dan penyerapan. ${ }^{5}$ Mengunyah dapat meningkatkan digestibilitas dan penyerapan karbohidrat dalam beberapa cara; pemecahan ukuran partikel akan meningkatkan pengiriman makanan dari lambung ke usus halus, luas permukaan yang lebih besar dari makanan yang dikunyah meningkatkan akses ke enzim pankreas, dan peningkatan jumlah saliva terkait aktivitas mengunyah akan meningkatkan pencernaan makanan di mulut dan lambung. 5,34

Pada kelompok mengunyah 40 kali tiap suapan terdapat penurunan kadar glukosa postprandial kembali seperti semula sebelum dilakukan perlakuan yang mendukung penelitian sebelumnya oleh Suzuki, dkk yang menyatakan bahwa pada subjek dengan toleransi glukosa normal memiliki kapasitas sekresi insulin fase awal yang cukup untuk menurunkan konsentrasi glukosa plasma setelah penyerapan glukosa yang lebih cepat pada perlakuan mengunyah lebih lama. Dalam penelitian tersebut juga membuktikan mengunyah lama efektif dalam sekresi insulin dari 5 menit (fase sefalik) hingga 90 menit setelah makan yang menghasilkan konsentrasi glukosa postprandial lebih rendah setelah 30 menit. $^{11}$

Kadar glukosa postprandial 60 menit dan 120 menit antara kedua kelompok tidak terdapat perbedaan bermakna. Hal ini menunjukkan bahwa banyak kunyahan dapat berpengaruh pada normalisasi glukosa postprandial meskipun kadar glukosa puasa pada kelompok 40 kali kunyahan tiap suapan lebih tinggi dibanding dengan kelompok 22 kali mengunyah tiap suapan. Normalisasi toleransi kadar glukosa postprandial ini terjadi karena adanya peran dari GLP-1. Pada penelitian sebelumnya oleh Kokkinos, dkk menyatakan bahwa GLP-1 mengalami peningkatan lebih tinggi pada kelompok yang mengunyah lebih lama. ${ }^{35}$ GLP-1 merupakan hormon inkretin yang berfungsi dalam meningkatkan pelepasan insulin setelah intak glukosa secara oral atau ada perangsangan glukosa di dalam usus sehingga insulin akan menurunkan konsentrasi glukosa darah menjadi normal. ${ }^{36,37}$

Respon sefalik berperan penting dalam homeostatis dan tahap persiapan traktus gastrointestinal untuk penyerapan dan absorbsi zat gizi yang optimal. Tektur makanan dan mastikasi dapat mengatur regulasi sekresi saliva dan mempengaruhi stimulasi orosensorik. ${ }^{5}$ Hal ini menunjukkan bahwa kebiasaan makan yang baik mencegah terjadinya diabetes dengan memperbaiki metabolisme glukosa setelah makan. ${ }^{38}$

\section{SIMPULAN}

Terdapat penurunan kadar glukosa darah postprandial yang lebih rendah pada kelompok 
mengunyah 40 kali tiap suapan dibandingkan kelompok mengunyah 22 kali tiap suapan pada dewasa obesitas. Kadar glukosa darah postprandial 15 menit antara kelompok mengunyah 40 kali tiap suapan dan kelompok mengunyah 22 kali tiap suapan terdapat perbedaan yang bermakna secara statistik pada dewasa obesitas, sementara kadar glukosa darah postprandial 30 menit, 60 menit, dan 120 menit antara kelompok mengunyah 40 kali tiap suapan dan kelompok mengunyah 22 kali tiap suapan tidak terdapat perbedaan yang bermakna secara statistik pada dewasa obesitas.

Penelitian selanjutnya diharapkan dapat menggunakan jumlah rerata mengunyah berdasarkan kebiasaan masing-masing subjek. Selain itu, perlu dilakukan perbandingan pengaruh lama mengunyah terhadap kadar glukosa postprandial antara kelompok penderita obesitas dengan kelompok IMT normal.

\section{UCAPAN TERIMA KASIH}

Penelitian ini didanai dari Program Kreativitas Mahasiswa Kemenristekdikti 2018.

\section{DAFTAR PUSTAKA}

1. World Health Organization (WHO). Obesity and Overweight [Internet]. 2017 [cited 2018 Jun 20]. Available from: http://www.who.int/newsroom/fact-sheets/detail/obesity-and-overweight

2. Litbangkes. Riset Kesehatan Dasar. Jakarta: Kemenkes RI; 2013. p. 223.

3. Al-hazzaa HM, Abahussain NA, Al-sobayel HI, Qahwaji DM, Musaiger AO. Lifestyle factors associated with overweight and obesity among Saudi adolescents. BMC Public Health. 2012;12(1):1-11.

4. Azrin NH, Kellen MJ, Brooks J, Ehle C, Vinas V. Relationship between rate of eating and degree of satiation. Child Fam Behav Ther. 2008;30(4):35564.

5. Li J, Zhang N, Hu L, Li Z, Li R, Li C, et al. Improvement in chewing activity reduces energy intake in one meal and modulates plasma gut hormone concentrations in obese and lean. Am J Clin Nutr. 2011;(3):709-16.

6. Hassoon SM, Zadian MA. Obesity and Overweight among Sample of Foundation of Technical Education Students in Iraq During 2011. Med J Babylon. 2013;10(1):162-72.

7. Guyton AC, Hall JE. Buku Ajar Fisiologi Kedokteran. Edisi 12. Jakarta: EGC; 2014. 855-922 p.

8. Soegondo S. Sindroma Metabolik. In: Sudoyo, A.W., Setiyohadi, B., Alwi, I., Simadibrata, M., Setiasti, S. E, editor. Buku Ilmu Penyakit Dalam Jilid 3. 5th ed. Jakarta: Departemen Ilmu Penyakit
Dalam Fakultas Kedokteran Universitas Indonesia; 2009. p. 1865.

9. Arisman. Obesitas, Diabetes Mellitus dan Dislipidemia. In: Mahode, AA, editor. Buku Ajar Ilmu Gizi. Jakarta: EGC; 2011.

10. Cassady BA, Hollis JH, Fulford AD, Considine R V., Mattes RD. Mastication of almonds: Effects of lipid bioaccessibility, appetite, and hormone response. Am J Clin Nutr. 2009;89(3):794-800.

11. Suzuki H, Fukushima M, Okamoto $S$, Takahashi O, Shimbo T. Effects of thorough mastication on postprandial plasma glucose concentrations in nonobese Japanese subjects. Elsevier. 2005;54(12):1593-9.

12. Zhu Y, Hsu WH, Hollis JH. Increased number of chews during a fixed-amount meal suppresses postprandial appetite and modulates glycemic response in older males. Physiol Behav. 2014; 133:136-40.

13. Forde CG, Kuijk N Van, Thaler T, Graaf C De, Martin N. Oral Processing Characteristics Of Solid Savoury Meal Components, And Relationship With Food Composition, Sensory Attributes And Expected Satiation. Appetite [Internet]. 2013;60:208-19. Available from: http://dx.doi.org/10.1016/j.appet.2012.09.015

14. Park S, Shin W. Differences In Eating Behaviors And Masticatory Performances By Gender And Obesity Status. Physiol Behav [Internet]. 2015;138:69-74. Available from: http://dx.doi.org/10.1016/j.physbeh.2014.10.001

15. Hollis JH. The Effect Of Mastication On Food Intake, Satiety And Body Weight. Physiol Behav [Internet]. 2018;(October 2017):0-1. Available from:

https://doi.org/10.1016/j.physbeh.2018.04.027

16. Leong SL, Madden C, Gray A, Waters D, Horwath C. Faster Self-Reported Speed of Eating Is Related to Higher Body Mass Index in a Nationwide Survey of Middle-Aged Women. J Am Diet Assoc [Internet]. 2011;111(8):1192-7. Available from: http://dx.doi.org/10.1016/j.jada.2011.05.012

17. Zhu Y, Hsu WH, Hollis JH. Increasing the number of masticatory cycles is associated with reduced appetite and altered postprandial plasma concentrations of gut hormones, insulin and glucose. Br J Nutr. 2013;110(2):384-90.

18. Yamin, Bahrudin; Nelly Mayulu JR. Hubungan Asupan Energi dengan Kejadian Obesitas pada Siswa Sekolah Dasar di Kota Manado. ejournal keperawatan. 2013;1(1):1-8.

19. Li L, Li X, Zhou W, L. Messina J. Acute Psychological Stress Results in the Rapid Development of Insulin Resistance. J Endcrinology. 2013;217(2):175-84.

20. Spiegel K, Knutson K, Leproult R, Tasali E, Cauter 
E Van, Knutson K, et al. Sleep loss : a novel risk factor for insulin resistance and Type 2 diabetes. J Appl Physiol. 2005;99(5):2008-19.

21. Hashimoto K, Matsuda H, Fujimasa H, Yurikusa M. Effects of mastication on glucose metabolism in rats, with emphasis on differences in properties of food consumed whilst breeding. Arch Oral Biol [Internet]. 2011;56(12):1610-5. Available from: http://dx.doi.org/10.1016/j.archoralbio.2011.06.01 5

22. Ranawana V, Henry CJK, Pratt M. Degree of habitual mastication seems to contribute to interindividual variations in the glycemic response to rice but not to spaghetti. Nutr Res [Internet]. 2010;30(6):382-91. Available from: http://dx.doi.org/10.1016/j.nutres.2010.06.002

23. Apolzan JW, Leidy HJ, Mattes RD, Campbell WW. Effects of food form on food intake and postprandial appetite sensations, glucose and endocrine responses, and energy expenditure in resistance trained v. sedentary older adults. Br J Nutr. 2011;106(7):1107-16.

24. Zhu Y, Hsu WH, Hollis JH. The effect of food form on satiety. Int J Food Sci Nutr. 2013;64(June):38591.

25. Pereira LJ, Gaviao MBD, Engelen L, Bilt AV. Mastication And Swallowing: Influence Of Fluid Addition To Foods. J Appl Oral Sci. 2007; 15(1):5560.

26. Shirali A, Pawaskar PN. Mastication Frequency and Postprandial Blood Sugar Levels in Normoglycaemic and Dysglycaemic Individuals : A Cross- Sectional Comparative Study. J Clin Diagn Res. 2016;10(7):OC06-08.

27. Takeshi K, Seino Y, Nishi S, Tsuji K, Taminato T, Tsuda K, et al. Mechanism of Sympathetic Neural Regulation of Insulin, Somatostatin, and Glucagon Secretion. Am J PhysiolPhysiol. 1990;258:E220-7.

28. Ramussen H, Zawalich KC, Ganesan S, Calle R, Zawalich WS. Physiology and Pathophysiology of Insulin Secretion. Diabetes Care. 1990;13(6):65566.

29. Kim W, Egan JM. The Role of Incretins in Glucose Homeostasis and Diabetes Treatment. Pharmacol Rev. 2009;60(4):470-512.
30. Ma J, Bellon M, Wishart JM, Young R, Blackshaw $\mathrm{LA}$, Jones $\mathrm{KL}$, et al. Effect of the artificial sweetener, sucralose, on gastric emptying and incretin hormone release in healthy subjects. Am J Physiol Gastrointest Liver Physiol. 2009;296(4):735-9.

31. Meutia N. Peran Neuropeptida Y dalam Meningkatkan Nafsu Makan. e-USU Repos. 2005; 1-14.

32. Meutia N. Peran Hormon Ghrelin Dalam Meningkatkan Nafsu Makan. e-USU Repos. 2005;(3):1-11.

33. Astuti R, Hendriyani H. Penambahan kelapa (Cocos nucifera) dan kacang tolo (Vigna unguiculata) terhadap nilai indeks glikemik singkong (Manihot utilissima). J Gizi Klin Indones. 2013;10(1):1-9.

34. Read NW, Welch IM, Austen CJ, Barnish C, Bartlett CE, Baxter AJ, et al. Swallowing food without chewing; a simple way to reduce postprandial glycaemia. $\mathrm{Br} \mathrm{J}$ Nutr [Internet]. 1986;55(1):43-7. Available from: http://www.ncbi.nlm.nih.gov/pubmed/3311145

35. Kokkinos A, Le Roux CW, Alexiadou K, Tentolouris N, Vincent RP, Kyriaki D, et al. Eating slowly increases the postprandial response of the anorexigenic gut hormones, peptide YY and glucagon-like peptide-1. J Clin Endocrinol Metab. 2010;95(1):333-7.

36. Jang H-J, Kokrashvili Z, Theodorakis MJ, Carlson OD, Kim B-J, Zhou J, et al. Gut-expressed gustducin and taste receptors regulate secretion of glucagon-like peptide-1. Proc Natl Acad Sci [Internet]. 2007;104(38):15069-74. Available from:

http://www.pnas.org/cgi/doi/10.1073/pnas.070689 0104

37. Soelistijo SA, Novida H, Rudijanto A, Soewondo P, Suastika K, Manaf A et al. Konsensus Pengelolaan dan Pencegahan Diabetes Melitus Tipe 2 di Indonesia 2015. 2015. 27-29 p.

38. Yamazaki T, Yamori M, Asai K, Nakano-Araki I, Yamaguchi A, Takahashi K, et al. Mastication and Risk for Diabetes in a Japanese Population: A Cross-Sectional Study. PLoS One. 2013;8(6):1-8. 